\title{
The influence of minisett size and time of planting on the yield of seed yam (Dioscorea Rotundata)
}

\author{
Beatrice Aighewi $^{1 \text { ^*}(\mathbb{D}) \text {, Norbert Maroya }}{ }^{2}$, Djana Mignouna ${ }^{3}$, Daniel Aihebhoria ${ }^{1}$, Morufat Balogun $^{2,4}$ \\ and Robert Asiedu ${ }^{2}$ \\ ${ }^{1}$ International Institute of Tropical Agriculture, Abuja, Nigeria, ${ }^{2}$ International Institute of Tropical Agriculture, Ibadan, \\ Nigeria, ${ }^{3}$ International Institute of Tropical Agriculture, Cotonou, Republic of Benin and ${ }^{4}$ University of Ibadan, Ibadan, \\ Nigeria \\ *Corresponding author. Email: b.aighewi@cgiar.org
}

(Received 19 June 2019; revised 16 April 2020; accepted 29 April 2020)

\begin{abstract}
In traditional yam (Dioscorea spp.) production systems in West Africa, finding sole seed yam producers is rare and up to $30 \%$ of harvested tubers from the ware tuber crop is reserved to plant an equivalent area of the harvested crop during the next season. Many farmers typically must make a trade-off between food and seed in the use of available tubers. A study was carried out using a factorial experiment in a randomised complete block design to investigate the influence of planting different minisett sizes at different planting periods on the yield of seed yam with the aim of improving the availability of this expensive input and saving more ware tubers for food or sale. Results showed that by doubling or tripling the minisett size from 30 to 60 or $90 \mathrm{~g}$, yields of seed yam increased by 61.1 and $103.3 \%$, respectively. The $90 \mathrm{~g}$ minisetts had the highest values for all traits studied but had the least sett multiplication ratio. The early planted crop yielded $137 \%$ more than the late-planted crop. Significant interactions between minisett size, planting period and season were found. In 2016, although the highest yield of seed tubers was from early planted $90 \mathrm{~g}$ minisetts $\left(35.6 \mathrm{t} \mathrm{ha}^{-1}\right)$, the yield of early planted $30 \mathrm{~g}$ minisetts $\left(23.8 \mathrm{t} \mathrm{ha}^{-1}\right)$ was similar to those of $60 \mathrm{~g}$ planted mid-season $\left(28.7 \mathrm{t} \mathrm{ha}^{-1}\right)$ and $90 \mathrm{~g}$ planted late $\left(20.0 \mathrm{t} \mathrm{ha}^{-1}\right)$. To produce a high proportion of seed size tubers with less planting material, early planting of $30 \mathrm{~g}$ minisetts is recommended. Such practice will enhance seed tuber availability and food security by saving $1-2 \mathrm{t} \mathrm{ha}^{-1}$ of tubers that would have been used as seed instead of food.
\end{abstract}

Keywords: Minisett size; Planting time; Seed yam

\section{Introduction}

The family Dioscoreaceae to which yam belongs contains an estimated 600 species. Only six principal species are grown for consumption, while several others are produced for medicinal purposes (Okwu and Ndu, 2006). Although West Africa produces about $93 \%$ of global yam output, the crop is grown in many other tropical countries outside the region (FAO, 2018). The most important species used as food in the yam belt of West Africa is D. rotundata, while D. alata is more cosmopolitan. Yam is a major staple and provides food for millions of people and income for smallholder farmers, processors and marketers in the region. Apart from providing about 32\% of farm income in southeast Nigeria (IITA, 1987), the tuber also serves as a major source of foreign exchange especially for some South American producers and Ghana. Yam tubers have a shelf 
life that is longer than for other root and tuber crops, and thus contribute more to food security during long periods when other foods are scarce (Osunde and Orhevba, 2009).

Between 1961 and 2017, there were increases in world yam production from 8.3 to 73.0 million tonnes, whereas the area under production rose from 1.2 to 8.6 million hectares and yields increased from 7.2 to $8.5 \mathrm{t} \mathrm{ha}^{-1}$ (FAO, 2018). Thus, the increase in production can be attributed mainly to the larger land area planted. Major constraints responsible for the slow rate of increase in yam productivity especially in West Africa have been identified to include non-availability, high cost and poor quality of planting materials, pests and diseases, as well as declining soil fertility (Tetteh and Saakwa, 1994). Limitation in the supply of seed yam results from the fact that most farmers depend largely on their own production with only a small proportion being obtained from the market (Asumugha et al., 2007). The absence of specialised seed producers is an indication that seed yam found in markets is often the leftovers after farmers have planted or reserved enough quantities to plant their own fields. The prevalent practice of saving planting material from a ware yam (food) crop reduces quantities that would have been saved for food, as well as impact negatively on the growth of yam-based enterprises. This situation has persisted because farmers are yet to explore the option of separating the production of seed and ware yam crops.

For commercial production, yam is vegetatively propagated by planting tuber pieces or whole tubers. In traditional systems, the planting material which could also be used as food is bulky (200-500 g per plant), has a low multiplication ratio of less than 1:10, and sometimes its scarcity results in unplanted mounds in farmers' fields (Aighewi, 1998; Ezeh, 1998). In some cases, after planting, a batch of seed yam is further reserved to replace those that do not sprout for various reasons. The reserved seed is an avoidable cost, considering that seed yam may constitute more than $40 \%$ of the production cost.

The minisett technique of seed yam production developed by the International Institute of Tropical Agriculture (IITA) and National Root Crops Research Institute of Nigeria in the late 1970s was aimed at improving the availability of seed yam. It involves cutting tubers of up to $1000 \mathrm{~g}$ into minisetts of 25-100 g, with each containing part of the cortex and periderm. The minisetts are treated in a mixture of fungicide and insecticide before planting to produce small whole seed tubers mostly in the range of 300-500 g but also up to $1000 \mathrm{~g}$ (Aighewi et al., 2014). The minisett technique increases the multiplication ratio to about 1:30, and the seed size tubers produced are planted to obtain ware yam tubers. Although the adoption rate of this seed production technique has been low (Morse, 2018), it remains a viable option for farmers to rapidly multiply yam, especially when faced with the uncertainty of weather.

Timing is crucial in determining the success of agricultural activities. In this regard, the global changes in climate pose risks which are generally believed to be more acute in developing countries (Chikezie et al., 2015). This climatic condition introduces anomalies in the onset, cessation and duration of annual rains and could be a major challenge to yam production in rainfed agriculture where most cultivated varieties grow for 7-10 months. With an early cessation of rains, farmers risk losing planting materials in traditional yam production systems that practice two harvests per yam stand. The first harvest is for food and the second for seed tubers (Aighewi et al., 2014). In this system, a tuber is harvested carefully without destroying the corm and root system of the plant at between 5 and 7 months after crop emergence. The corm and roots are covered again with soil for the tuber piece left on the plant to continue bulking. At the end of the season (total senescence), a second harvest is done and the produce is used as seed. Whether a single or double harvest, tubers are sorted by size at final harvest, and those above $1000 \mathrm{~g}$ are typically reserved for food, while smaller tubers are saved for use as seed. Thus, early cessation of rains can drastically reduce the yield of the second harvest, leaving the farmer with a loss of seed.

Using the minisett technique, a seed yam crop is normally produced over a period of about 5 months (IITA, 1987), which fits into the rainy season of the southern Guinea Savanna agroecology in Nigeria where most yam is produced. For ware yam production, it has been established that planting should be done early in the season, sometimes before the onset of rains (November to March). 


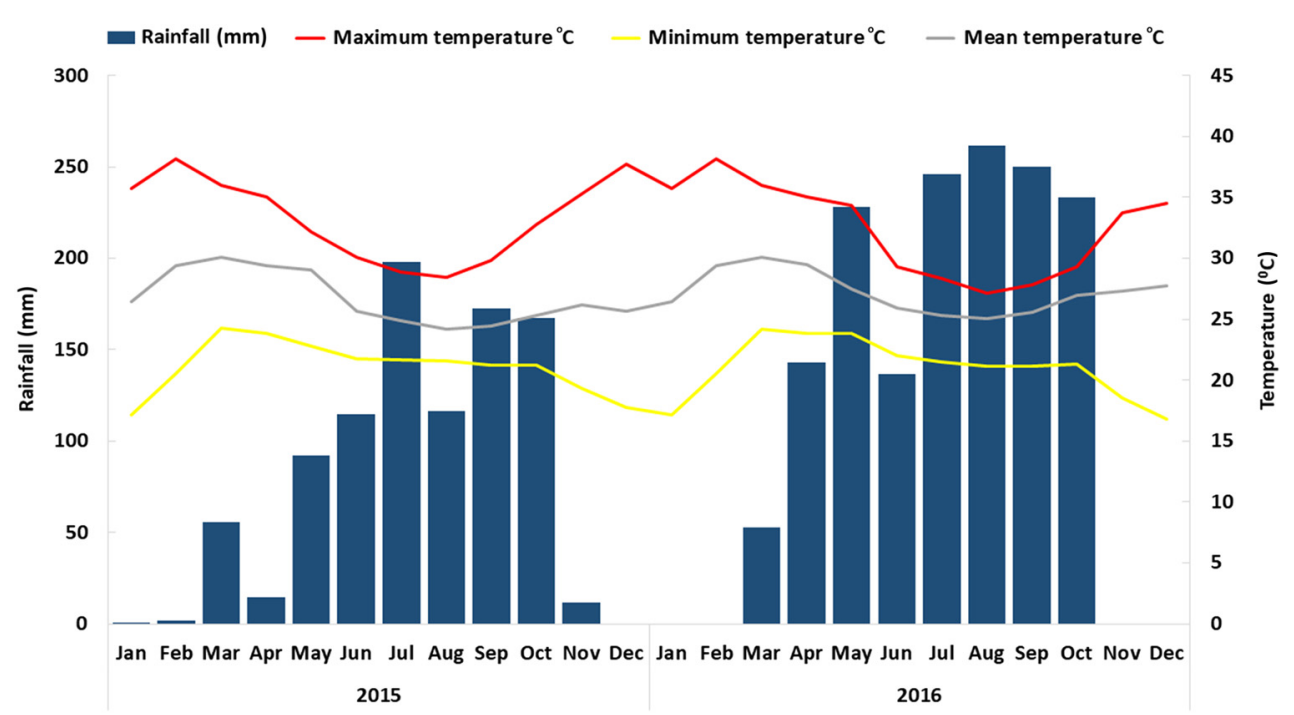

Figure 1. Monthly rainfall and air temperature during the cropping seasons of 2015 and 2016 in Abuja, Nigeria.

The problem with early planting is that temperatures are usually high and planted setts may rot in the soil if not well-mulched. Another issue with early planting, especially at the beginning of the rainy season, is the probability of having a poor crop establishment if the rains are irregular. Dry spells during the early growth stages of yam have led to low ware yam production in many yam-growing areas of Nigeria (Eruola et al., 2012). Late planting may result in reduced crop duration and tuber yield. However, to produce large ware tubers, the crop must stay in the field for 7-12 months depending on variety and species (Onwueme, 1978). It is not certain how the yield of seed yam will be impacted by timing the planting of different sizes of minisetts.

This paper presents the results of a study of the effects of period of planting and minisett size on the yield of seed yam, which are considered here as tubers of about 20-1000 g. We expect that the knowledge obtained will guide extensionists and seed producers or companies to establish seed yam enterprises to supply their needs and the market, as well as reduce the quantity of food yam that is currently used as seed.

\section{Materials and Methods}

The trial was carried out on the experimental field at the Abuja Station (9.164694 N, 7.345136 E) of the IITA, which is located in the yam belt of Nigeria, during the cropping seasons of 2015 and 2016. In both seasons, 945.7 and $1552.2 \mathrm{~mm}$ of rain fell between March and October, in 2015 and 2016, respectively (Figure 1). The average minimum air temperatures were 21.0 and $21.1^{\circ} \mathrm{C}$ in 2015 and 2016, respectively, while the average maximum air temperatures were 32.4 and $33.3^{\circ} \mathrm{C}$ for both seasons.

The experiment was laid out in a randomised complete block design with three replications and the following nine treatment combinations: $30 \mathrm{~g}$ minisetts planted early (early); $30 \mathrm{~g}$ minisetts planted 21 days after the early planting (mid) and $30 \mathrm{~g}$ minisetts planted 21 days after the mid planting (late). Similarly, $60 \mathrm{~g}$ and $90 \mathrm{~g}$ minisetts were planted early, mid and late, respectively. Whole tubers of the $D$. rotundata landrace 'Meccakusa' were cut into three minisett sizes of 30, 60 and $90 \mathrm{~g}$. The minisetts were treated by dipping into a chemical mix containing a broad-spectrum fungicide ( $100 \mathrm{~g}$ Mancozeb) and an insecticide ( $40 \mathrm{~mL}$ Lambda-cyhalothrin) in $10 \mathrm{~L}$ of water for 10 minutes. The minisetts were then air-dried under shade for 24 hours before planting. The early plantings were done on 2 June 2015 and 6 May 2016 in the first and second 
year, respectively. The second or mid plantings were done on 23 June 2015 and 27 May 2016, while the third or late plantings took place on 14 July 2015 and 17 June 2016, respectively.

The experimental plots used for the 2015 crop went through a yearly rotation of yamAeschynomene histrix-Mucuna spp-yam, while the plot used in 2016 had a crop of maize in the previous season, after a fallow of about 20 years. The plots were disc-harrowed and made into 9-m long ridges spaced $1 \mathrm{~m}$ apart. Minisetts were planted at a depth of about $7 \mathrm{~cm}$ in single rows on top of the ridges at $0.3-\mathrm{m}$ interval. At 6 weeks after planting (WAP), all plants were staked using about $1.5-\mathrm{m}$ long bamboo poles on which a cord was tied, and plants directed (twined) to the cord using strings. No fertiliser was applied to the soil, and weeding was done manually as needed using hand hoes.

Data on crop establishment were based on all surviving stands in a plot, while other agronomic data such as length of the principal vine, number of vines and number of leaves were obtained from five randomly selected plants per treatment at 9 WAP for each planting date. Data on the five plants were used to calculate mean values per plant. The time to $50 \%$ shoot emergence was recorded for each treatment. Fresh tuber weight per plot was obtained at harvest, while the tuber yield in $\mathrm{tha}^{-1}$ and sett multiplication ratio (SMR) were calculated after harvest, as shown in eqn. 1.

$$
\mathrm{SMR}=\frac{\text { Weight of harvested tubers }}{\text { Weight of the planted material }}
$$

All harvesting for each year was done on the same date: 17 December 2015 and 20 December 2016 after 4-5 weeks of complete foliage senescence. Thus, in 2015 the early, mid and late crops were harvested at 28, 25 and 22 WAP, respectively, while in 2016 they were harvested at 32, 29 and 26 WAP, respectively. Harvested tubers were sorted into four categories, counted and weighed. Data were analysed using the Statistical Analysis System (SAS Institute Inc., 2016). Mean values were significantly different and were separated using the least significant difference at $p \leq 0.05$.

A stepwise regression $\left(r^{2}\right)$ analysis was performed where fresh tuber yield $\left(\mathrm{t} \mathrm{ha}{ }^{-1}\right)$ was the dependent variable. The percent field establishment, vine length, number of leaves and number of vines (main vine and branches) were independent variables used to quantify the individual effect on fresh tuber yield. Partial regression coefficients were expressed as a percentage and used to measure the effect of each trait after the effect of all others was removed from the model.

\section{Results}

The time of planting and size of minisett significantly $(p \leq 0.05)$ influenced the outcome of the fresh tuber yield and its related parameters such as the crop establishment, number and length of vines, number of leaves, leaf area index, mean tuber weight and number of tubers per plant as detailed in Table 1. The effect of minisett size on the number of days to $50 \%$ emergence and full crop establishment was not significant, although the largest minisetts established slightly better over a shorter period. The length of vines and number of leaves per plant were significantly higher for 60 and $90 \mathrm{~g}$ minisetts than for those of $30 \mathrm{~g}$ (Table 2). Minisetts of $90 \mathrm{~g}$ had on average 53.3 and $22.1 \%$ more leaves than 30 and $60 \mathrm{~g}$ minisetts, respectively. Plants from the largest minisetts had almost twice as many vines which were $46.7 \%$ longer than those from $30 \mathrm{~g}$ minisetts. There were substantial differences in the performance of different sizes of minisetts in fresh tuber yield, with the $90 \mathrm{~g}$ minisetts producing the highest yield and the $30 \mathrm{~g}$ minisetts the lowest. By doubling or tripling the minisett size from $30 \mathrm{~g}$, yields increased by 61.1 and $103.3 \%$, respectively. However, increasing the seed size from 60 to $90 \mathrm{~g}$ recorded a yield increase of only $26.2 \%$. The $90 \mathrm{~g}$ minisetts had the least SMR, which was comparable to that of $60 \mathrm{~g}$ minisetts. The biggest (mean weight of $0.5 \mathrm{~kg}$ ) and smallest (mean weight of $0.3 \mathrm{~kg}$ ) seed tubers were produced by the 90 and $30 \mathrm{~g}$ minisetts, respectively. The earlier the period of planting, the bigger the seed yam produced, with the early planting having tubers that were about $200 \%$ bigger than those of late planting. The mean 
Table 1. Analysis of variance of the yield and yield-related traits of seed yam produced from different sizes of minisetts planted at various periods in Abuja, Nigeria

\begin{tabular}{|c|c|c|c|c|c|c|c|c|c|}
\hline & $\begin{array}{l}\text { Source of } \\
\text { variation }\end{array}$ & Sett size & $\begin{array}{l}\text { Time of } \\
\text { planting }\end{array}$ & Year & $\begin{array}{l}\text { Sett size } \times \text { time of } \\
\text { planting }\end{array}$ & Sett size $\times$ year & $\begin{array}{c}\text { Time of } \\
\text { planting } \times \text { year }\end{array}$ & $\begin{array}{l}\text { Sett size } \times \text { time of } \\
\text { planting } \times \text { year }\end{array}$ & Residual \\
\hline & D.F. & 2.0 & 2.0 & 1.0 & 4.0 & 2.0 & 2.0 & 4.0 & 34.0 \\
\hline \multirow[t]{3}{*}{ Days to $50 \%$ emergence } & S.S. & 75.1 & 869.8 & 10.7 & 108.4 & 12.0 & 21.8 & 30.9 & 562.9 \\
\hline & M.S & 37.6 & 434.9 & 10.7 & 27.1 & 6.0 & 10.9 & 7.7 & 16.6 \\
\hline & F.pro & 0.1 & $<0.001$ & 0.4 & 0.2 & 0.7 & 0.5 & 0.8 & \\
\hline \multirow[t]{3}{*}{ Crop establishment (\%) } & S.S. & 99.1 & 599.1 & 108.9 & 181.1 & 52.2 & 85.6 & 210.8 & 686.0 \\
\hline & M.S & 49.6 & 299.6 & 108.9 & 45.3 & 26.1 & 42.8 & 52.7 & 20.2 \\
\hline & F.pro & 0.1 & $<0.001$ & 0.0 & 0.1 & 0.3 & 0.1 & 0.1 & \\
\hline \multirow[t]{3}{*}{ Vine length $(\mathrm{m})$} & S.S. & 3.7 & 5.1 & 1.8 & 1.1 & 0.1 & 0.6 & 0.4 & 14.4 \\
\hline & M.S & 1.9 & 2.6 & 1.8 & 0.3 & 0.1 & 0.3 & 0.1 & 0.4 \\
\hline & F.pro & 0.0 & 0.0 & 0.1 & 0.6 & 0.8 & 0.5 & 0.9 & \\
\hline \multirow[t]{3}{*}{ No. of vines } & S.S. & 170.2 & 107.2 & 82.6 & 17.2 & 0.4 & 6.3 & 64.4 & 155.8 \\
\hline & M.S & 85.1 & 53.6 & 82.6 & 4.3 & 0.2 & 3.2 & 16.1 & 4.6 \\
\hline & F.pro & $<0.001$ & $<0.001$ & $<0.001$ & 0.5 & 1.0 & 0.5 & 0.0 & \\
\hline \multirow[t]{3}{*}{ No. of leaves } & S.S. & 6124.9 & 2001.5 & 770.4 & 620.4 & 72.8 & 29.7 & 353.9 & 2834.2 \\
\hline & M.S & 3062.5 & 1000.8 & 770.4 & 155.1 & 36.4 & 14.8 & 88.5 & 83.4 \\
\hline & F.pro & $<0.001$ & $<0.001$ & 0.0 & 0.1 & 0.7 & 0.8 & 0.4 & \\
\hline \multirow[t]{3}{*}{ Fresh tuber yield $\left(\mathrm{t} \mathrm{ha}^{-1}\right)$} & S.S. & 796.8 & 1099.4 & 4505.1 & 85.1 & 386.7 & 493.4 & 97.8 & 426.1 \\
\hline & M.S & 398.4 & 549.7 & 4505.1 & 21.3 & 193.4 & 246.7 & 24.5 & 12.5 \\
\hline & F.pro & $<0.001$ & $<0.001$ & $<0.001$ & 0.2 & $<0.001$ & $<0.001$ & 0.1 & \\
\hline \multirow[t]{3}{*}{ Sett multiplication ratio } & S.S. & 168.7 & 594.4 & 941.5 & 161.9 & 17.4 & 89.2 & 52.3 & 445.7 \\
\hline & M.S & 84.4 & 297.2 & 941.5 & 40.5 & 8.7 & 44.6 & 13.1 & 13.1 \\
\hline & F.pro & 0.0 & $<0.001$ & $<0.001$ & 0.0 & 0.5 & 0.0 & 0.4 & \\
\hline \multirow[t]{3}{*}{ Mean tuber weight (kg) } & S.S. & 0.3 & 0.9 & 3.1 & 0.0 & 0.1 & 0.4 & 0.0 & 0.4 \\
\hline & M.S & 0.2 & 0.5 & 3.1 & 0.0 & 0.1 & 0.2 & 0.0 & 0.0 \\
\hline & F.pro & $<0.001$ & $<0.001$ & $<0.001$ & 0.5 & 0.0 & $<0.001$ & 0.8 & \\
\hline \multirow[t]{3}{*}{ Number of tubers/plant } & S.S. & 0.2 & 0.2 & 0.0 & 0.1 & 0.1 & 0.2 & 0.1 & 0.8 \\
\hline & M.S & 0.1 & 0.1 & 0.0 & 0.0 & 0.1 & 0.1 & 0.0 & 0.0 \\
\hline & F.pro & 0.0 & 0.0 & 0.3 & 0.2 & 0.1 & 0.0 & 0.3 & \\
\hline
\end{tabular}


Table 2. The effects of different minisett sizes and period of planting of Dioscorea rotundata variety, Meccakusa, in Abuja during 2015 and 2016 seasons

\begin{tabular}{|c|c|c|c|c|c|c|c|c|c|c|}
\hline & Factor & $\begin{array}{l}\text { Days to } 50 \% \\
\text { emergence }\end{array}$ & $\begin{array}{c}\text { Crop } \\
\text { establishment } \\
(\%)\end{array}$ & $\begin{array}{l}\text { Vine length } \\
(\mathrm{m})\end{array}$ & $\begin{array}{l}\text { Number of } \\
\text { vines }\end{array}$ & $\begin{array}{l}\text { Number of } \\
\text { leaves }\end{array}$ & $\begin{array}{l}\text { Yield } \\
\left(\mathrm{t} \mathrm{ha}^{-1}\right)\end{array}$ & $\begin{array}{l}\text { Sett } \\
\text { multiplication } \\
\text { ratio }\end{array}$ & $\begin{array}{l}\text { Mean tuber } \\
\text { weight }(\mathrm{kg})\end{array}$ & $\begin{array}{l}\text { Number of } \\
\text { tubers/plant }\end{array}$ \\
\hline \multirow[t]{4}{*}{ Minisett size } & $30 \mathrm{~g}$ & $47.6 a$ & $89.1 a$ & $1.5 \mathrm{a}$ & $4.8 a$ & $49.0 \mathrm{a}$ & $9.0 \mathrm{a}$ & $12.4 b$ & $0.3 a$ & $1.1 \mathrm{a}$ \\
\hline & $60 \mathrm{~g}$ & $45.1 a$ & $88.9 a$ & $2.0 \mathrm{~b}$ & $6.1 a$ & $61.5 b$ & $14.5 b$ & $9.8 a$ & $0.4 b$ & $1.2 b$ \\
\hline & $90 \mathrm{~g}$ & $45.0 a$ & $91.9 a$ & $2.2 \mathrm{~b}$ & $9.1 b$ & $75.1 \mathrm{c}$ & $18.3 c$ & $8.1 a$ & $0.5 c$ & $1.2 b$ \\
\hline & LSD (5\%) & 2.76 & 3.03 & 0.44 & 1.45 & 6.18 & 2.40 & 2.45 & 0.07 & 0.10 \\
\hline \multirow[t]{3}{*}{ Seasons } & 2015 & $46.3 a$ & $88.5 a$ & $1.7 a$ & $5.4 a$ & $58.1 a$ & $4.8 a$ & $5.9 a$ & $0.2 \mathrm{a}$ & $1.2 \mathrm{a}$ \\
\hline & 2016 & $45.4 a$ & $91.4 b$ & $2.1 b$ & $7.9 b$ & $65.6 b$ & $23.1 b$ & $14.3 b$ & $0.6 b$ & $1.2 \mathrm{a}$ \\
\hline & LSD (5\%) & 2.25 & 2.49 & 0.36 & 1.18 & 5.05 & 1.99 & 2.00 & 0.06 & 0.08 \\
\hline \multirow[t]{4}{*}{ Planting period } & Early & $40.4 a$ & $93.9 c$ & $2.3 \mathrm{~b}$ & $8.4 c$ & $69.0 \mathrm{c}$ & $18.7 \mathrm{c}$ & $13.8 \mathrm{c}$ & $0.6 c$ & $1.1 \mathrm{a}$ \\
\hline & Mid & $47.2 b$ & $90.2 b$ & 1.9ab & $6.7 \mathrm{~b}$ & $62.4 \mathrm{~b}$ & $15.2 \mathrm{~b}$ & $10.7 \mathrm{~b}$ & $0.4 \mathrm{~b}$ & $1.2 \mathrm{a}$ \\
\hline & Late & $50.0 \mathrm{c}$ & $85.7 a$ & $1.5 a$ & $4.9 a$ & $54.1 \mathrm{a}$ & $7.9 a$ & $5.8 a$ & $0.2 \mathrm{a}$ & $1.2 \mathrm{a}$ \\
\hline & LSD (5\%) & 2.76 & 3.04 & 0.44 & 1.45 & 6.18 & 2.40 & 2.45 & 0.07 & 0.10 \\
\hline
\end{tabular}

Means with the same alphabet along column are not significantly different at $p \leq 0.05$. 
seed yam size was bigger in the second season. The time and season of planting had no significant effects on the number of tubers produced per plant. The 60 and $90 \mathrm{~g}$ minisetts were at par with regard to the number of tubers per plant, both producing more tubers than the $30 \mathrm{~g}$ minisetts.

There were significant differences in all the traits measured due to the time and season of planting of the minisetts. Those planted early significantly outperformed those that were planted at mid-season, which were, in turn, better than the late-planted minisetts (Table 2). By planting late, up to $14.3 \%$ of the stands failed to establish compared to 9.8 and $6.1 \%$ of mid-season and early plantings, respectively. Late planting also led to significant reductions in the number of leaves and vines per plant as well as the length of vines. Yield and SMR of the early-planted crop were significantly better than those from the mid-season crop, which were, in turn, better than those from the late-planted crop. The yield of the early planted crop was more than double (159.7\%) that of late planting and increased by $23 \%$ over the mid-season planting.

Significant interactions were observed between minisett size, time and season of planting as shown in Table 3. The best crop establishment was obtained from the early planted $90 \mathrm{~g}$ minisetts in 2016 (98.9\%). This was similar to the 30 and $60 \mathrm{~g}$ minisetts planted early and $90 \mathrm{~g}$ minisetts planted mid-season in 2016 (95.6, 96.7 and 93.3\%, respectively), as well as the $30 \mathrm{~g}$ minisetts planted mid-season and late-planted $90 \mathrm{~g}$ minisetts in 2015 (96.6\%). The shortest period to $50 \%$ crop establishment (38.7 days) was from the early planting of $90 \mathrm{~g}$ minisetts in 2015 and the longest period was from the late-planted $30 \mathrm{~g}$ minisetts in 2015 (56.3 days). The early planted 90 g minisetts of 2016 produced the highest seed yam yields $\left(35.6 \mathrm{t} \mathrm{ha}^{-1}\right)$, followed by the mid-season planting of the same size and year $\left(35.5 \mathrm{t} \mathrm{ha}^{-1}\right)$, both being similar to the yield of early planted $60 \mathrm{~g}$ minisetts in $2016\left(33.1 \mathrm{t} \mathrm{ha}^{-1}\right)$. The lowest yield of $1.4 \mathrm{t} \mathrm{ha}^{-1}$ was obtained from the late-planted $30 \mathrm{~g}$ minisetts in 2015. Yields were similarly low for all the treatments of 2015, except the early planted $90 \mathrm{~g}$ minisetts. Generally, for all minisett sizes, planting early gave higher yields than later plantings (Table 3). The highest SMR value of 26.6 was obtained from the early planting of $30 \mathrm{~g}$ minisetts, followed by that of $60 \mathrm{~g}$ minisetts in 2016 (18.4), while the least was from the late-planted $60 \mathrm{~g}$ minisetts in 2015 (2.5). Results of the other traits measured, and their interactions are presented in Table 3 . These results clearly indicate that the 2016 crop performed better with yields that were 4-5 times higher than those of 2015 .

A stepwise regression analysis showed that the number of leaves and vines significantly $(p<0.05)$ accounted for 31.9 and $8.0 \%$, respectively, of the total variation of fresh tuber yield as per the regression eqn. 2 :

$$
\text { Tuber yield }(\mathrm{t} / \mathrm{ha})=-11.44+0.26(\text { No. of leaves })+1.39 \text { (No. of vines) }
$$

In addition, there was a significant reduction in yield from other sources as given by a negative intercept in the regression equation.

At harvest, the tubers were categorised into different sizes and the general trend was that the smaller the minisett size, the smaller the seed tuber produced, and the earlier the planting period for any of the minisett sizes, the larger the size of tubers and yield (Figure 2). Hence, the largest proportion of tubers that weighed more than $1 \mathrm{~kg}$ (40.7\%) was obtained from $90 \mathrm{~g}$ minisetts that were planted early, while the least was obtained from $30 \mathrm{~g}$ minisetts that were planted late (2.3\%). Similarly, while late planting of $60 \mathrm{~g}$ minisetts yielded about $24 \%$ of tubers weighing less than $100 \mathrm{~g}$, only $6.4 \%$ of such tubers were produced when the same minisett size was planted early. Despite the overall lower yields obtained from late planting, it produced the highest percentage of seed tubers that could be planted whole.

An analysis of the soil in the experimental plot used in 2015 gave a $\mathrm{pH}\left(\mathrm{H}_{2} \mathrm{O}\right)$ of 5.7, soil organic carbon of $0.51 \%$, total $\mathrm{N}$ of $0.04 \%$, Meh $\mathrm{P}$ of $4.2 \mathrm{ppm}$, exchangeable $\mathrm{K}$ of $0.13 \mathrm{cmol} \mathrm{kg}^{-1}$ and CEC of $1.27 \mathrm{cmol} \mathrm{kg}^{-1}$. In 2016, the plot had a $\mathrm{pH}\left(\mathrm{H}_{2} \mathrm{O}\right)$ of 6.4 , soil organic carbon of $0.84 \%$, total $\mathrm{N}$ of $0.06 \%$, Meh P of $23.2 \mathrm{ppm}$, exchangeable $\mathrm{K}$ of $0.23 \mathrm{cmol} \mathrm{kg}^{-1}$ and CEC of $3.26 \mathrm{cmol} \mathrm{kg}^{-1}$. In both years, the soils had a sandy loam texture. 
Table 3. Interactions between the size of minisetts and period of planting on the yield of seed yam in Abuja, Nigeria during 2015 and 2016 seasons

\begin{tabular}{|c|c|c|c|c|c|c|c|c|c|c|c|}
\hline $\begin{array}{l}\text { Sett } \\
\text { size }\end{array}$ & $\begin{array}{l}\text { Planting } \\
\text { time }\end{array}$ & Year & $\begin{array}{c}\text { Days to } 50 \% \\
\text { emergence }\end{array}$ & $\begin{array}{c}\text { Crop } \\
\text { establishment } \\
(\%)\end{array}$ & $\begin{array}{l}\text { Vine length } \\
\text { (m) }\end{array}$ & $\begin{array}{l}\text { Number of } \\
\text { leaves }\end{array}$ & $\begin{array}{c}\text { Number of } \\
\text { vines }\end{array}$ & $\begin{array}{l}\text { Yield } \\
\left(\mathrm{t} \mathrm{ha}^{-1}\right)\end{array}$ & $\begin{array}{l}\text { Sett } \\
\text { multiplication } \\
\text { ratio }\end{array}$ & $\begin{array}{l}\text { Mean tuber } \\
\text { weight }(\mathrm{kg})\end{array}$ & $\begin{array}{l}\text { Number of } \\
\text { tubers/plant }\end{array}$ \\
\hline \multirow[t]{6}{*}{$30 \mathrm{~g}$} & Early & 2015 & 42.3abcde & $85.6 a b$ & $1.7 \mathrm{~b}$ & $48.8 \mathrm{abc}$ & 3.9abcd & $4.8 a b c$ & $11.6 \mathrm{cdefg}$ & $0.2 a b$ & $1.2 a b c$ \\
\hline & & 2016 & $40.0 \mathrm{abc}$ & 95.6def & $2.1 \mathrm{bc}$ & 57.3abcd & 7.2defg & $23.8 \mathrm{fg}$ & $26.6 \mathrm{i}$ & $0.7 \mathrm{e}$ & $1.0 \mathrm{a}$ \\
\hline & Mid & 2015 & 47.3def & 96.7ef & $1.6 a b$ & $46.3 a b$ & $3.6 a b c$ & $3.9 a b c$ & 8.2abcde & $0.1 a$ & $1.1 \mathrm{ab}$ \\
\hline & & 2016 & 47.3def & 88.9abcd & $1.7 \mathrm{~b}$ & $54.5 \mathrm{abc}$ & 7.9efg & $12.5 \mathrm{e}$ & $14.9 \mathrm{fgh}$ & $0.4 \mathrm{~cd}$ & $1.0 \mathrm{a}$ \\
\hline & Late & 2015 & $56.3 \mathrm{~g}$ & $84.5 a b$ & $0.6 a$ & $42.5 a$ & $3.0 \mathrm{ab}$ & $1.4 a$ & $3.4 a$ & $0.1 a$ & $1.2 a b c$ \\
\hline & & 2016 & $52.0 \mathrm{fg}$ & $83.3 a$ & $1.5 \mathrm{ab}$ & $44.5 a b$ & $3.4 a b c$ & 7.4bcde & 9.6bcdef & $0.2 \mathrm{ab}$ & $1.2 \mathrm{abc}$ \\
\hline \multirow[t]{6}{*}{$60 \mathrm{~g}$} & Early & 2015 & 41.7abcde & 90.0 abcde & $2.0 \mathrm{bc}$ & $62.7 \mathrm{cde}$ & 7.2defg & 7.1abcde & 7.8abcde & $0.2 a b$ & $1.2 a b c$ \\
\hline & & 2016 & $40.7 \mathrm{abcd}$ & $96.7 \mathrm{ef}$ & $2.3 b c$ & 74.9efg & $9.0 \mathrm{fg}$ & 33.1hi & $18.4 \mathrm{~h}$ & $1.0 f$ & $1.1 \mathrm{ab}$ \\
\hline & Mid & 2015 & 46.7cdef & $86.7 a b c$ & $1.9 b c$ & $54.0 \mathrm{abc}$ & 6.0bcdef & $4.8 \mathrm{abc}$ & $5.6 a b c$ & $0.2 \mathrm{ab}$ & $1.1 \mathrm{ab}$ \\
\hline & & 2016 & 46.0bcdef & 88.9abcd & $2.0 \mathrm{bc}$ & $62.2 \mathrm{cde}$ & $5.4 \mathrm{bcde}$ & 28.7gh & 17.4gh & $0.7 \mathrm{e}$ & $1.4 \mathrm{~cd}$ \\
\hline & Late & 2015 & 47.3def & $85.6 a b$ & $1.6 \mathrm{ab}$ & $59.6 \mathrm{bcd}$ & $1.5 a$ & 2.1ab & $2.5 a$ & $0.1 a$ & $1.2 a b c$ \\
\hline & & 2016 & 48.3ef & $85.6 a b$ & $2.0 \mathrm{bc}$ & 55.9abcd & 7.6efg & $11.2 \mathrm{de}$ & 7.1abcd & $0.3 b c$ & $1.3 \mathrm{bc}$ \\
\hline \multirow[t]{7}{*}{$90 \mathrm{~g}$} & Early & 2015 & $38.7 a$ & 96.7ef & $2.8 \mathrm{c}$ & $81.8 \mathrm{fg}$ & 8.9efg & $8.1 \mathrm{cde}$ & $5.6 \mathrm{abc}$ & $0.2 a b$ & $1.1 \mathrm{ab}$ \\
\hline & & 2016 & 39.3ab & $98.9 f$ & $2.8 \mathrm{c}$ & $88.7 \mathrm{~g}$ & $14.1 \mathrm{~h}$ & $35.6 \mathrm{i}$ & 12.9defgh & $1.0 f$ & $1.1 \mathrm{ab}$ \\
\hline & Mid & 2015 & $46.7 \mathrm{cdef}$ & 86.7abc & $1.8 \mathrm{bc}$ & 75.3efg & 7.6efg & $5.7 \mathrm{abcd}$ & $4.4 \mathrm{ab}$ & $0.2 \mathrm{ab}$ & $1.2 a b c$ \\
\hline & & 2016 & $49.3 f$ & 93.3cdef & $2.2 \mathrm{bc}$ & $82.1 \mathrm{fg}$ & $9.7 \mathrm{~g}$ & $35.5 i$ & 13.6efgh & $0.7 e$ & $1.6 \mathrm{~d}$ \\
\hline & Late & 2015 & $50.0 f g$ & $84.5 a b$ & $1.4 \mathrm{ab}$ & $51.9 \mathrm{abc}$ & 7.3defg & $5.2 \mathrm{abc}$ & $4.1 \mathrm{ab}$ & $0.2 a b$ & $1.2 a b c$ \\
\hline & & 2016 & 46.0bcdef & 91.1bcde & $2.1 \mathrm{bc}$ & 70.5def & 6.8cdefg & $20.0 f$ & 7.9abcde & $0.5 \mathrm{~d}$ & $1.3 \mathrm{bc}$ \\
\hline & & $\begin{array}{l}\text { LSD } \\
(5 \%)\end{array}$ & 6.75 & 7.45 & 1.08 & 15.15 & 3.55 & 5.87 & 6.01 & 0.17 & 0.25 \\
\hline
\end{tabular}

Means with the same alphabet along column are not significantly different at $p \leq 0.05$. 


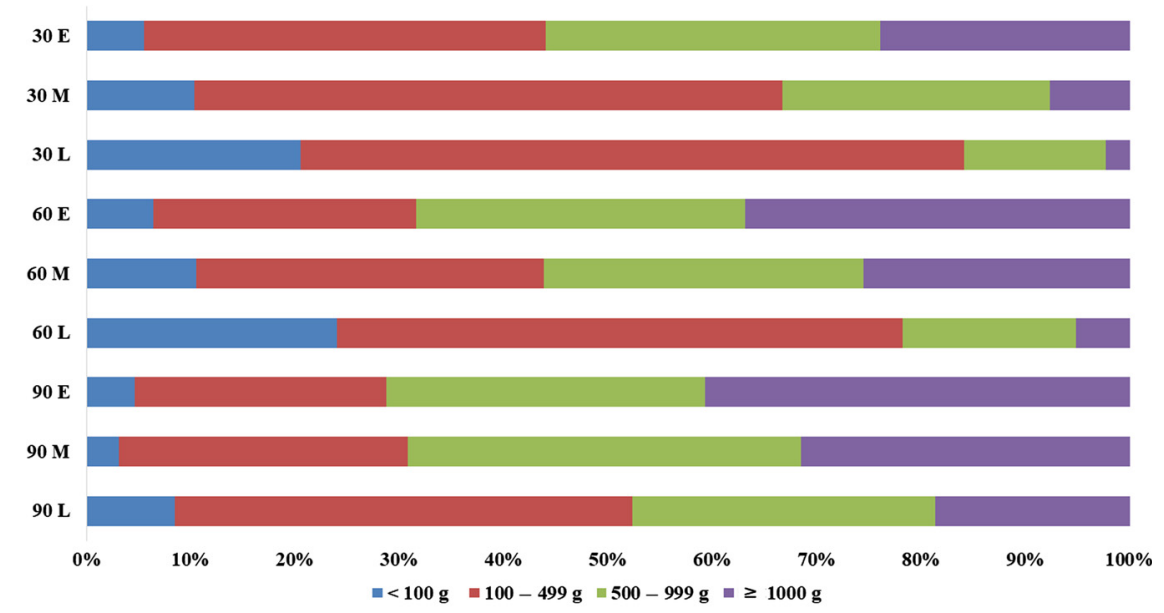

Figure 2. Proportion (\%) of different weights of tubers produced by different sizes of minisetts planted at different periods. $\mathrm{E}=$ early planting, $\mathrm{M}=$ mid-season planting, $\mathrm{L}=$ late planting. Tubers $<100 \mathrm{~g}$ are planted whole to produce bigger seed yams; tubers of 100-499 g could be planted whole, cut into two setts before planting to produce ware tubers of about 2-5 kg or cut into minisetts for further seed production; tubers of 500-999 g could be planted whole for extra-large ware tubers, cut into 2-4 setts for average size ware tuber production or cut into minisetts; tubers of $>1000 \mathrm{~g}$ are normally cut into more than four setts for ware yam production or used for food.

\section{Discussion}

\section{Effect of minisett size}

The weight of planted minisetts had significant effects on the number and length of vines, number of leaves, as well as tuber yield, with the bigger minisetts performing better (Table 2). The $90 \mathrm{~g}$ minisetts were only slightly better than those of $30 \mathrm{~g}$ in the earliness to attain $50 \%$ emergence and crop establishment, though it was observed that crops from $30 \mathrm{~g}$ minisetts were less vigorous in growth. Onwueme (1984) reported that large yam setts emerge from the soil quicker and produced more vigorous sprouts, but small setts only produce small seed yam tubers, which will, in turn, produce medium size ware tubers. Law-Ogbomo and Remison (2009) had similar results and showed that plant growth parameters were better with increasing minisett size and the biggest minisetts had the highest yields. Tuber-raised yam plants are heterotrophic in the first 2-3 months of planting, while depending on the food reserve in the tubers (Osunde and Orhevba, 2009) before becoming autotrophic when reserves in the planted seed tuber are exhausted. At that time, the effect of soil and climatic factors become significant. Therefore, the bigger the size of the sett planted, the longer the plants depend less on the environment. Research on potato (Solanum tuberosum) indicated that taller plants had higher production of leaves and photosynthates (Zelelew et al., 2016). Another study on yam noted that vine length (plant height) in yam contributed to fresh tuber yield, although the magnitude of its effect varied (Alieu et al., 2012). The higher number of leaves associated with more vines per plant favours the production of more photosynthates, which results in bigger tubers and more yield. Onwueme (1975) stated that the higher yields from bigger setts could be due to a transfer of photosynthates from the planted setts directly into the new tuber when tuberisation starts. The poorer yield of smaller minisetts $(30 \mathrm{~g})$ is due to the limited nutrients available for initial growth and subsequent lower accumulation of photosynthates as was reflected in the high proportion of small size seed tubers produced (Figure 2). Small yam setts have also been associated with losses in the field due to dehydration, poor rooting and early weed competition (Orkwor and Ekanayake, 1998). 


\section{Effect of time of planting}

Whatever the sett size, late planting resulted in the least field establishment leading to lower yield than early planting (Table 3 ). Yam tubers continue to age after harvest and would break dormancy about 2-3 months after storage. Whether the tuber is planted or not, the sprout will continue to grow (except it is severed from the tuber) thus depleting the tuber of stored nutrients, which would have been used for initial robust growth in the field. The usual practice is for farmers to occasionally remove sprouts from seed tubers in storage if field conditions are not yet conducive for planting. Desprouting can be done several times depending on storage conditions and the time involved (Aighewi et al., 2014). The more the delay in planting seed yam, especially when stored under ambient conditions, the weaker the plants will be when they emerge from the soil and the more yield would be adversely affected. Associated with the delay in planting is the increase in the incidence of diseases and pests causing tuber rots in storage and field when the seed is eventually planted.

Any operation that favours the production of more leaves such as early planting and the use of large minisett size results in more yield so long as the optimum number of leaves for the space available is not exceeded. Early planted setts produce robust vines which in turn have more leaves for a longer period of tuber bulking. However, there is a need to strike a balance between the size of minisetts and when it should be planted. Short day-length stimulates tuber formation depending on the growth phase at which the short-day treatment was administered and the earliness to maturity of the varieties (Vaillant et al., 2002), but long days stimulate canopy development. In Nigeria, the day-length is longest (12.5 hours) in June, having increased from 11.6 hours in January, before decreasing until December. Earlier planting, therefore, witnessed increasing day-length and had more canopies which probably enhanced tuber bulking. In contrast, late planting had decreasing day-length which stimulated tuber initiation despite minimum canopy development, leading to lower tuber yields.

The timing of field activities is crucial in attaining optimum productivity especially in rainfed systems that are affected more by the global climate change. Yam requires an annual rainfall of about 1000-1500 $\mathrm{mm}$ distributed uniformly throughout the growing period of 7-9 months for ware tuber production (Orkwor and Ekanayake, 1998) with $1000 \mathrm{~mm}$ spread over 5-6 months for seed tuber production (Hahn et al., 1987). Early planting allows the crops to receive much of the seasonal rainfall, while late-planted yam receives inadequate moisture during the tuber bulking stage, thus reducing tuber yield. The high yield obtained with early planting $\left(18.7 \mathrm{t} \mathrm{ha}^{-1}\right)$ compared to the yield when planting was done 6 weeks later $\left(7.9 \mathrm{tha}^{-1}\right)$ is enormous, considering that to produce ware yam in West Africa, 200-500 g setts are planted for an average yield of $8.9 \mathrm{t} \mathrm{ha}^{-1}$ (FAO, 2018). In 2016, the $73.8 \%$ more precipitation received by the trial (1356.7 mm against $780.4 \mathrm{~mm}$ in 2015), earlier planting by 1 month and better soil nutrient status contributed to the higher yields obtained. Apart from the benefit of having more photosynthetic leaf area for bulking of tubers over a longer growing period, early planting also ensures the absorption of phosphorus and mineralised nitrogen which are naturally higher during early rains (Solubo, 1972; Okoh, 2004). With delayed planting, some of these natural sources of nutrients are lost to leaching after the early rains. Most yam farmers depend on natural soil fertility and only occasionally apply limited quantities of soil enhancing inputs (fertilisers and manures) for yam cultivation.

Farmers should choose a specific minisett size and planting time, based on the targeted tuber size and the purpose of production. For instance, to obtain a high proportion of seed tubers weighing between 100 and $999 \mathrm{~g}, 30 \mathrm{~g}$ minisett size should be planted during any of the periods covered in this study. Late planting of 60 and $90 \mathrm{~g}$ minisetts will also produce many seed size tubers but will require a large quantity of planting material, which would otherwise be used as food by the farmer or sold for income. However, if the desire is to have a high proportion of bigger tubers that could be used as food and/or seed, then 60 or $90 \mathrm{~g}$ minisetts should be planted early in the cropping 
season. The larger size minisetts are suitable to produce tubers weighing between 1000 and $1500 \mathrm{~g}$ or above which is the target of the export market for food. The rainfall pattern of the locality should also be taken into consideration. Where precipitation exceeds 8 months as would be more likely in the forest regions, yam farmers who are targeting small size ware yam tubers should plant small size minisetts because it will have adequate time to grow in the field and give the desired tuber size at harvest without moisture stress. However, if the rainfall duration is about 5 months, then bigger yam minisetts should be planted early.

\section{Yield difference due to the cropping history of experimental plots}

The remarkable 4- to 5-fold differences in yields observed between the first- and second-year crops (Tables 2 and 3) can be partly explained by the different cropping histories of the experimental plots. More than 20 years of fallow of the plot used in 2016 meant that more organic matter and other nutrients were available to the second-year crop as indicated in the soil analysis. This explains why in traditional systems that are dominated by resource-poor farmers, preference is for land that has been under long fallows for yam cultivation. Unfortunately, with increasing human populations, such fertile lands are getting scarce with the resultant sub-optimal yam yields, since soil replenishing inputs are not applied.

\section{Impact on the SMR}

The SMR indicates the proportion of multiplication of the planted sett. This study revealed a reduction in SMR with an increase in minisett size (Table 2) and confirmed the findings of an earlier study (Onwueme, 1978). Although larger minisetts produced larger tubers, the increase in yield was not proportional to the additional increase in minisett size. So, there is an equilibrium beyond which further increase in sett size will result in a waste of tubers as planting material. For example, it has been observed that doubling the weight of yam setts from 125 to $250 \mathrm{~g}$ may only increase tuber yield by 20-30\% (Lyonga et al., 1973). Consequently, the SMR is greater for smaller setts. However, another study which assessed the influence of different minisett sizes $(25-50 \mathrm{~g})$ on the profit realisable from yam production in the Forest and Forest-Savanna transition zones of Edo State in Nigeria showed that the economic returns increased with increasing minisett size, with the highest gross margin and net returns obtained from $50 \mathrm{~g}$ minisett size in the Forest-Savanna zone (Emokaro and Law-Ogbomo, 2008).

\section{The implications for seed and food security}

Without considering the season of production, the $30 \mathrm{~g}$ minisetts planted early performed better (although not significantly) than $90 \mathrm{~g}$ setts when planted late. This implies that after emergence, plants from small-sized minisetts planted early had more access to available plant growth resources for a longer period resulting in yields which were equivalent to those of minisetts that were three times bigger and planted late. With $30 \mathrm{~g}$ minisetts planted at $30 \mathrm{~cm}$ spacing, the quantity of seed required per hectare is about 1 tonne. However, if $60 \mathrm{~g}$ or $90 \mathrm{~g}$ minisetts are used, an additional $1 \mathrm{t} \mathrm{ha}^{-1}$ and $2 \mathrm{t} \mathrm{ha}^{-1}$ of planting material would be needed, respectively. So, early planting would save this much tuber for use as food or sale in the market for income, though it may translate to a higher production cost as farmers must contend with maintaining the field for a longer period. Research has revealed that in small-scale production systems, common in West African agriculture, weeding alone could constitute $30-50 \%$ of the total labour budget depending on the crop species and the level of other applied resources (IITA, 1987; Akobundu, 1991). Hence, the economic implication of targeting a higher yield by allowing the crop in the field over a longer period needs to be evaluated. 
During a recent survey of yam farmers in Abuja, the Federal Capital Territory of Nigeria, by the authors, it was pointed out that a major reason for focusing on ware tuber instead of seed yam production was the fear that being a staple, food supply for their families would be limited if they concentrated on the production of seed yam. However, the results of the present study clearly showed that great savings can be made on food yam by reducing the sett size to 30-90 g minisetts for seed yam production and planting them early instead of the traditional practice of using 250-500 g setts for the dual purpose of ware and seed yam production. Also, if the cropping season is reduced by the early stoppage of rains, a small-scale farmer can still be guaranteed seed for the subsequent season. Tubers of various sizes and proportions can be harvested to meet the dual requirements of seed and food.

\section{Conclusion}

Yam is a valuable crop particularly in West Africa although obtaining enough seed tubers for increased production is a major challenge. This study evaluated the use of yam minisetts of different sizes and planted at different periods for seed production. There were significant differences between yields and other related parameters due to minisett size and planting date, as well as in interactions. Yield increased with increase in minisett size and reduced with the delay in the time of planting. The yield of $30 \mathrm{~g}$ minisetts planted early was at par with that of $90 \mathrm{~g}$ minisetts planted late. Savings of 1-2 $\mathrm{t} \mathrm{ha}^{-1}$ of tubers can be made for food by planting minisetts of $30 \mathrm{~g}$ early in the season instead of late planting of 60-90 g minisetts. However, the additional cost of crop maintenance over a longer growth period as well as the rainfall pattern of the location should be considered to decide on planting time. This study has demonstrated the flexibility of the adaptive minisett technique as farmers can choose planting times and sett sizes for specific varieties to match the targeted tuber size to be produced, to meet demands for food, seed and specific consumer markets.

\section{Acknowledgements. None.}

Financial support. The financial support of the Bill \& Melinda Gates Foundation under the Global Development Grant Number 0PP1003516-YIIFSWA: Yam Improvement for Income and Food Security in West Africa Project of the International Institute of Tropical Agriculture, Ibadan, Nigeria, September 8, 2011, is gratefully acknowledged.

\section{References}

Aighewi, B. A. (1998). Seed yam (Dioscorea rotundata Poir.) production and quality in selected yam zones of Nigeria. Ph.D. Thesis, University of Ibadan, Ibadan, Nigeria.

Aighewi, B. A., Maroya, N. G. \& Asiedu, R. (2014). Seed yam production from minisetts: A training manual. IITA, Ibadan, Nigeria, pp 40 (ISBN 978-978-8444-49-7).

Akobundu, I. O. (1991). Evaluation of glufosinate-ammonium for pre-plant weed control in a sub-humid forest ecology. Nigerian Journal of Weed Science 4: 35-42.

Alieu, S., Franco, J. \& Asiedu, R. (2012). Phenotypic analysis of tuber yield- and maturity-related traits in white yam (Dioscorea rotundata). ISSN 1684-5315, African Journal of Biotechnology 11(17): 3964-3975. doi: 10.5897/AJB11.1292.

Asumugha, G. N., Ugwu, B. O., Aniedu, O. C \& Orkwor, G. C. (2007). Seed yam marketing in Nigeria: Determinants and constraints. Proceedings of the 13th International Society of Tropical Root Crops Symposium, Kampala pp. 656-663.

Chikezie, C., Ibekwe, U. C., Ohajianya, D. O., Orebiyi, J. S., Ehirim, N. C. \& Henri-Ukoha, A. 1. (2015). Effect of climate change on food crop production in southeast, Nigeria: A co-integration model approach. International Journal of Weather, Climate Change and Conservation Research 2(1): 47-56.

Emokaro, C. O. \& Law-Ogbomo, K. E. (2008). The influence of minisett size on the profitability of yam production in Edo State, Nigeria. Research Journal of Agriculture and Biological Sciences 4(6): 672-675.

Eruola, A. O., Bello, N. J., Ufoegbune, G. C. \& Makinde, A. A. (2012). Application of rainfall-potential evapotranspiration model for determining optimum planting date of yam (Dioscorea rotundata) in a tropical wet-and-dry climate. International Journal of Plant Research 2(2): 36-40.

Ezeh, N. O. A. (1998). Economics of production and postharvest technology. In Food Yams - Advances in research, pp. 187-214 (Eds G. C. Orkwor, R. Asiedu and I. J. Ekanayake). IITA and NRCRI, Nigeria. 
Food and Agriculture Organization of the United Nations (FAO) (2018). Available from http://www.fao.org/faostat/en/ \#data/QC.

Hahn, S. K., Osiru, D. S. O., Akoroda, M. O. \& Otoo, J. A. (1987). Yam production and its future prospects. Outlook on Agriculture 16: 105-110. doi: 10.1177/003072708701600302.

International Institute of Tropical Agriculture (IITA) Ibadan, Nigeria. Annual report of 1987, pp. 37.

Law-Ogbomo, K. E. \& Remison, S.U. (2009). Influence of minisett sizes on dry matter accumulation and fresh tuber yield of white Guinea yam (Dioscorea rotundata). Annals of Applied Biology Vol 155(2): 201-206. http://doi.org/10.1111/j.17.447348.2009.00330.x.

Lyonga, S. N., Fayemi, A. A. \& Agboola, A. A. (1973). Agronomic studies on edible yams (Dioscorea spp.) in the grassland plateau region of the United Republic of Cameroon. Paper presented at the Third International Symposium of the Society for Tropical Root Crops, held at Ibadan, Nigeria.

Morse, S. (2018). Analysis of yam minisett technique adoption in Nigeria. Journal of Crop Improvement 32: 4, 511-531. doi: 10.1080/15427528.2018.1458365.

Okoh, C. A. (2004). The effect of mulching on soil physico-chemical properties and the yield of White Yam. Tropical Journal of Root Tuber Crops 4(2): 24-31.

Okwu, D. E. \& Ndu, C. U. (2006). Evaluation of the phytonutrients, mineral and vitamin contents of some varieties of yam (Dioscorea sp.). International Journal of Molecular Medicine and Advance Sciences 2(2): 199-203. http://medwelljournals. com/abstract/?doi=ijmmas.2006.199.203.

Onwueme, I. C. (1984). Yam. In The physiology of tropical field crops. (Eds P.R. Goldsworthy and N.M. Fisher). John Wiley and Sons Ltd. London, U.K.

Onwueme, I. C. (1978). The tropical root crops: yam, cassava, sweet potato and cocoyams. John Wiley and Sons, Chichester, pp 1-106.

Onwueme, I. C. (1975). Tuber formation in yam (Dioscorea spp.): Effect of moisture stress; contribution of the parent sett. The Journal of Agricultural Science (Camb) 85(2): 267-269. https://doi.org/10.1017/S0021859600062079.

Orkwor, G. C. \& Ekanayake, I. J. (1998). Growth and development. In Food Yams: Advances in research (Eds G. C. Orkwor, R. Asiedu and I. J. Ekanakaye) IITA and NRCRI, Nigeria, pp 105-141.

Osunde, Z. D. \& Orhevba, B. A. (2009). Effects of storage conditions and storage period on nutritional and other qualities of stored yam (Dioscorea spp.) tubers. African Journal of Food, Agriculture, Nutrition and Development 9(2): 678-690. doi: 10.4314/ajfand.v9i2.19219.

SAS Institute Inc. 2016. SAS Version 9.4. Cary, NC 27513-2414.

Solubo, R. A. (1972). Studies on white yam (Dioscorea rotundata). II. Changes in nutrient with age. Experimental Agriculture 8: 107-115. doi: 10.1017/S0014479700005056.

Tetteh, J. P. \& Saakwa, C. (1994). Prospects and constraints to yam production in Ghana. In Tropical root crops in a developing economy (Eds F. Ofori and S. K. Hahn). Proceedings of ninth Triennial Symposium of the International Society of Tropical Root Crops, 20-26 October, Accra Ghana, pp. 355-9.

Vaillant, V., Bade, P. \& Constant, C. (2002). Photoperiod affects the growth and development of yam plantlets obtained by in vitro propagation. Biologia Plantarum. 49: 355. https://doi.org/10.1007/s10535-005-0007-8.

Zelelew, D. Z., Lal, S., Kidane, T. T. \& Biniam, M. G. (2016). Effect of potassium levels on growth and productivity of potato varieties. American Journal of Plant Sciences 7, 1629-1638. http://dx.doi.org/10.4236/ajps.2016.712154.

Cite this article: Aighewi B, Maroya N, Mignouna D, Aihebhoria D, Balogun M, and Asiedu R (2020). The influence of minisett size and time of planting on the yield of seed yam (Dioscorea Rotundata). Experimental Agriculture 56, 469-481. https://doi.org/10.1017/S0014479720000095 